\title{
Economic growth and income concentration and their effects on poverty in Brazil
}

\author{
Jair Andrade Araujo, Emerson Marinho \\ and Guaracyane Lima Campêlo
}

\begin{abstract}
We use panel data for Brazilian states from 1995 to 2009 to analyse the impact of economic growth and income inequality on poverty change in Brazil, seeking to evaluate the Bourguignon (2003) hypothesis that the more unequal a country is, the less effective economic growth will be at reducing poverty. To this end, we estimate poverty elasticities relative to income and inequality, specifying two dynamic econometric models estimated via the generalized method of moments (GMM) system developed by Arellano and Bond (1991), Arellano and Bover (1995) and Blundell and Bond (1998). The model-estimated results prompt the conclusion that the income growth effect on poverty reduction is smaller when the initial development level is low. The same is found when the initial inequality level is high. Therefore, regions with a low initial development level, high initial inequality or both present less favourable conditions for reducing poverty through income growth.
\end{abstract}

\section{Keywords}

Economic growth, income distribution, poverty, poverty mitigation, econometric models, Brazil

JEL classification

D60, D63, C33

\section{Authors}

Jair Andrade Araujo is a professor on the Rural Economy master's degree course and Head of the Department of Agricultural Economics at the Federal University of Ceará, Brazil. Email: jairandrade@ufc.br.

Emerson Marinho is a professor on the Economics postgraduate programme at the Federal University of Ceará, Brazil. Email: emarinho@ufc.br.

Guaracyane Lima Campêlo is a professor with the Department of Economics and Finance at the Sobral campus of the Federal University of Ceará, Brazil. Email: cyanelc@gmail.com. 


\section{Introduction}

Many countries' development policies are mainly focused on improving the well-being of the population. Of the many goals this entails, poverty reduction is fundamental, especially considering that poverty often proves persistent despite the economy's rising capacity to generate wealth.

According to Rocha (2006), it is clear that economic expansion does not necessarily benefit everyone in a given society even when achieved successfully. Rich countries are evidently struggling to eliminate residual poverty, while economic growth in developing countries has exacerbated social inequalities.

The question of how changes in income and inequality affect poverty reduction has been brought to the fore in recent years by the proven fact that economic growth has yet to resolve poverty issues in many countries.

For example, Cline (2004) studied several countries during the 1990s and concluded that poverty did fall in many of them as a consequence of economic growth. However, some countries that did not enjoy significant economic growth were also successful in reducing poverty. This shows that economic growth by itself cannot explain poverty changes and that income inequality is of paramount importance as a poverty reduction factor.

Chen and Wang (2001) investigated poverty and inequality in China during the 1990s. After decomposing the poverty changes caused by economic growth and by shifts in inequality, they concluded that it was the rich who profited most from economic growth, as the average income of the wealthiest $20 \%$ increased by more than the average income overall. This highlights the importance of income inequality as a variable in poverty reduction.

Barros, Henriques and Mendonça (2001) found that the incidence of poverty was higher in Brazil than in most countries with similar per capita incomes. They concluded that income inequality was the reason why economic growth was relatively inefficient at reducing poverty. In other words, the effect of economic growth on poverty reduction was smaller in Brazil than in other countries with the same income level.

If any change in poverty is the consequence of income redistribution or economic growth (or both), the importance of each effect should be identified. Recent studies have sought to explain which factors affect the income-poverty and inequality-poverty elasticities.

For example, Ravallion and Chen (1997) used a sample of developing countries to demonstrate income-poverty elasticity (measured by the number of people with incomes below the poverty line of one dollar a day), finding this elasticity to be -3 . This means that for every $1 \%$ rise in the average income, the proportion of individuals with incomes below the poverty line falls by $3 \%$. However, there are countries that have been able to reduce household poverty without significant economic growth.

Bourguignon (2003) estimated income-poverty elasticity for a set of countries, using a log-normal distribution to approximate income distribution. He demonstrated that the higher the average income and the lower its concentration, the higher the resulting elasticity.

Empirical evidence in the case of Brazil has been provided by Marinho and Soares (2003), who estimated the average income elasticity of poverty in the Brazilian states from 1985 to 1999. They concluded that a higher average income resulted in a higher absolute elasticity and that higher income concentration led to lower absolute elasticity. The highest income-poverty elasticity values were found in the states of São Paulo and Rio de Janeiro.

In another study carried out for Brazil, Hoffman (2004) used a different methodology from that of Marinho and Soares (2003) to estimate these same elasticities. He found that both estimations showed very similar standard variations across the different states. 
Salvato and Araujo Junior (2007) used data from Brazilian municipalities to investigate the relationship between growth, poverty and inequality, measuring the elasticity of poverty relative to economic growth and changes in income inequality. They also tested for the existence of a non-linear interaction effect between growth and initial inequality, seeking to evaluate the hypothesis that higher inequality was associated with a lessening of the poverty reduction efficiency of growth. They found that of the major regions, the south-east boasted the highest elasticity, while São Paulo was the state that achieved the best results. They also noticed a negative correlation between the elasticity module and initial inequality, which implies that higher initial inequality means a diminution of the poverty reduction brought about by economic growth, corroborating the Bourguignon (2003) hypothesis. The results also suggest a negative correlation between redistribution elasticity and initial inequality.

However, these issues have not been fully clarified, since, according to Barreto (2005), there is still no consensus about the relationship between poverty, growth and inequality. Thus, it is extremely important to determine the effects that each of these factors exerts on poverty.

Measuring these elasticities is a vital part of planning for income growth and redistribution policies, considering that poverty reduction is affected both by shifts in economic growth and by inequality reduction, as Cline (2004) points out.

Taking these facts into consideration, the aim of this work is to analyse the impact of economic growth and shifts in income inequality on poverty changes in Brazil. Since growth alone cannot explain alterations in poverty levels, we treat income inequality as a factor in these, seeking to evaluate the hypothesis that the more unequal a country is, the less effective economic growth will be at reducing poverty (Bourguignon, 2003).

In order to verify these effects, we estimate the elasticity of poverty with respect to income and inequality. These latter variables are estimated by applying a dynamic econometric panel data model developed by Arellano and Bond (1991), Arellano and Bover (1995) and Blundel and Bond (1998). In the panel, the units of analysis are the Brazilian states during the period from 1995 to 2009.

The present article is composed of six sections besides this introduction. Section II reviews the Brazilian and international literature on the triangular relationship between poverty, economic growth and inequality, and offers a brief history of inequality in Brazil. Section III provides theoretical definitions of income-poverty and inequality-poverty elasticities. Section IV discusses the database, while section V introduces the econometric model and its estimation methods and presents an analysis of the results. Section VI contains analysis of the results and lastly, section VII draws the final conclusions.

\section{The triangular relationship between poverty, economic growth and inequality}

This section presents a review of the literature on the triangular relationship between poverty, economic growth and income inequality. The interaction of these three variables provides a sufficient basis for diagnosing the extent to which income growth or a decrease in inequality affects poverty reduction.

Bourguignon (2003) clearly describes what he calls the poverty-inequality-growth triangle, arguing that the three variables interact. In his article, he assumes the log-normality of income distribution and assigns changes in poverty levels to two different causes: (i) the growth effect, which arises when there is a proportional change in income levels not necessarily accompanied by any change in relative incomes, and (ii) the distribution effect, meaning a change in the distribution of relative income.

This approach can be used to demonstrate that changes in poverty levels may result from either economic growth (typified by increases in average income) or a lessening of income inequality. 
The curves in figure 1 show income distribution densities, represented on the horizontal axis by a logarithmic scale. The displacement from the initial distribution to the final one occurs through an intermediate step, which is the horizontal transposition of the initial distribution to curve (I). This change represents a proportional increase in all incomes across the population due to the growth effect.

\section{Figure 1}

Decomposition of poverty changes due to economic growth and income distribution

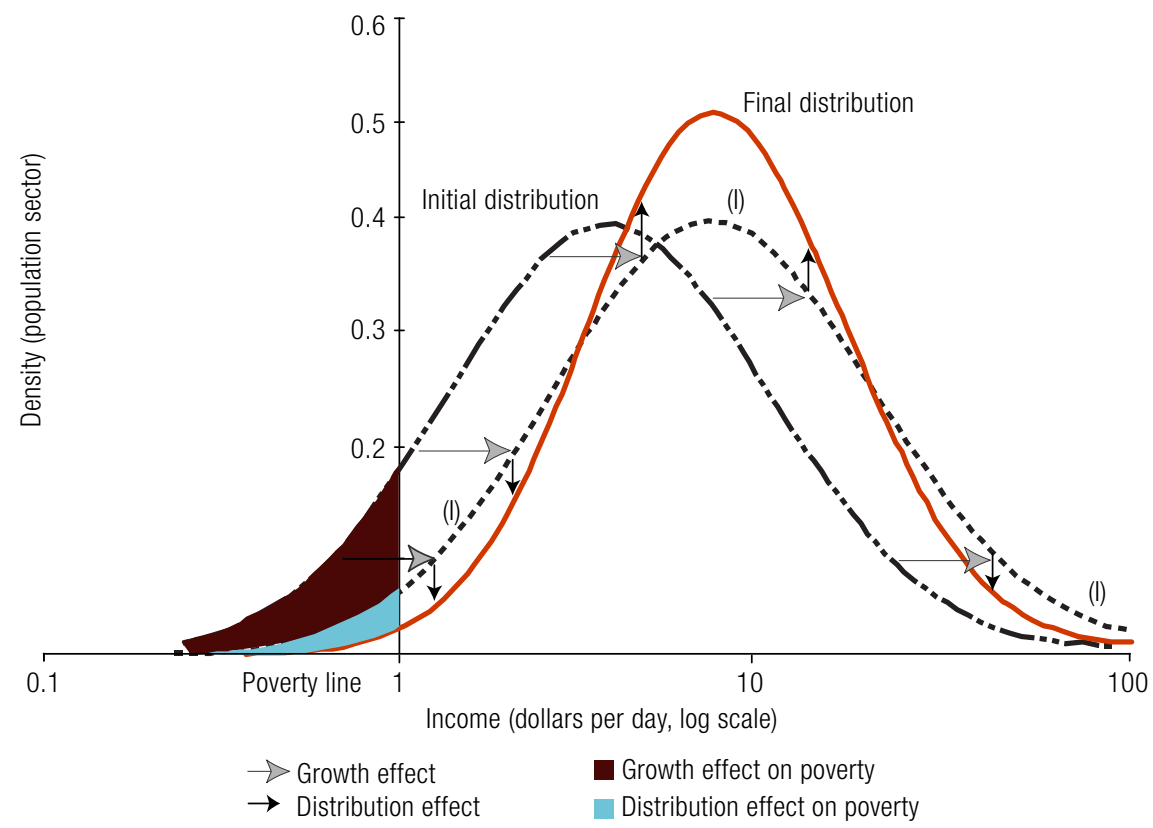

Source: F. Bourguignon, "The growth elasticity of poverty reduction: explaining heterogeneity across countries and time periods", Inequality and Growth: Theory and Policy Implications, T. Eicher and S. Turnovsky (eds.), Cambridge, Massachusetts, The MIT Press, 2003.

Thus, the change involves displacement of the income distribution density to the right. If $z$ is taken as the poverty line, it can be seen that there is a reduction in the number of poor individuals. This decline in the percentage of poor people is exclusively a consequence of the growth effect.

The shift of curve (I) towards the final distribution comes about with constant average income and a change in relative income distribution, this being the distribution effect. Thus, the poverty level falls without any alteration in the average income of the population because of a decrease in income inequality. In other words, a decrease in income concentration leads to a reduction in the number of people with incomes below the poverty line.

Bourguignon (2004) called this relationship the "poverty-inequality-growth triangle". Setting out from this, many studies have been undertaken to identify and measure the relationship between the effects of growth and changes in inequality on poverty reduction.

\section{Poverty versus economic growth}

Several empirical studies in Brazil and internationally have analysed the interactions between economic growth and poverty. There seems to be a broad consensus among researchers that two factors are fundamental in the study of poverty reduction: the average growth rate and initial income inequality.

For example, Kraay (2004) carried out a poverty variance decomposition to ascertain the importance of economic growth in poverty reduction, using a sample of developing countries during 
the 1980s and 1990s. His analysis concluded that changes in poverty indices were due to average income growth, the implication being that policies to promote economic growth were essential for the well-being of the poor.

The relationship between growth and poverty reduction can be measured by the income elasticity and growth elasticity equations. If elasticity is high, public anti-poverty policies based on economic growth are more efficient. If elasticity is low, however, poverty reduction strategies should include a combination of economic growth and some type of income redistribution. Ravallion and Chen (1997) estimated income-poverty and inequality-poverty elasticities for 45 countries. The results for low-inequality countries showed that if income increased by $1 \%$, poverty was reduced by $4.3 \%$. In countries where inequality was high, however, the decline in poverty with the same growth would be only $0.6 \%$. The conclusion was that growth in itself had little effect on poverty, but that if inequality tended to decline because of the growth, the effect on poverty was much stronger.

In another study, Ravallion (2001) found that growth-poverty elasticity was much higher in countries that combined growth with some kind of inequality reduction policy. This suggests that the growth-poverty elasticity methodology needs to be controlled for the income redistribution component.

As an example, Ravallion (2005) estimated pro-poor growth in China and India in the 1990s and found that changes in income distribution disadvantaged the poor, as the income growth rate for this population sector was lower than overall ordinary income growth during the period analysed. This result yielded a growth incidence curve with a positive slope for the highest income levels. However, pro-poor income growth was still positive, suggesting a decline in absolute poverty.

Chen and Wang (2001) studied the relationship between poverty, income and inequality in China during the 1990s. They concluded that while economic growth tended to reduce poverty, income concentration tended to increase it. They also found that the growth in average income was more beneficial for the rich, as only the average income of the richest $20 \%$ grew by more than average income overall, showing that income concentration reduces the positive effect of economic growth on poverty levels.

Stewart (2000) estimated that a gross domestic product (GDP) growth rate of $1.0 \%$ prompted a $0.21 \%$ decline in poverty in Zambia, while the same change led to a $3.4 \%$ decline in poverty in Malaysia, the discrepancy being due to the differences in income inequality between the two countries.

Bearing out these findings, Deininger and Squire (1996) analysed the potential effect of economic growth in reducing inequality for a sample of several countries, finding that different inequality levels had different consequences for economic growth and that these levels were negatively related to poverty.

Using a sample of 84 countries between 1996 and 2000, Son (2004) showed that economic growth contributed to poverty reduction in $95 \%$ of cases. In the others, either the growth rate was negative or it was not possible to draw conclusions because of sampling ambiguities.

The Brazilian literature includes some studies on these subjects. For example, Hoffmann (1995) found a reduction in poverty levels during the 1970s, with high income growth and relatively unchanged inequality. In the 1980s, poverty and inequality increased due to extremely high inflation.

In another study, Hoffmann (2005) found that a 1\% increase in per capita household income in Brazil led to a reduction of $0.84 \%$ in the proportion of poor people and that the absolute value of this elasticity increased with income and decreased with a reduction in inequality.

Marinho and Soares (2003), using data from 26 Brazilian states between 1985 and 1999, applied a methodological procedure that allowed poverty changes resulting from alterations in average income and income concentration to be decomposed. The results showed that income concentration had a greater influence than income levels in all the northern states. Likewise, income growth was of strategic importance in fighting poverty. Generally speaking, their study showed that higher average rates resulted in a higher absolute elasticity while greater income concentration meant a lower absolute elasticity. 
Manso, Barreto and Tebaldi (2005) searched National Household Survey (PNAD) data from 1995 to 2004 for evidence of the interactions between income growth, poverty reduction and the wealth distribution profile. In their study, these authors widened the discussion on the problem of regional imbalance in Brazil by evaluating the impact of economic growth on poverty rates. Their analysis allowed economic growth and income inequality effects in each region of the country to be isolated. The results suggest that average income growth and income distribution components are sufficient to explain most of the variations in poverty in Brazilian states. Findings so far reinforce the evidence that policies aimed at fighting poverty through economic growth are more efficient when accompanied by positive income redistribution.

\section{Poverty versus inequality}

This subsection investigates the relationship between poverty and inequality in the literature. In general, many authors affirm that the percentage of poor people in a given region decreases when there is a policy of economic growth combined with income redistribution.

Income inequality is an important component in the debate on poverty. Poverty is a worldwide problem that affects modern society and has been discussed in numerous studies, persisting alongside the growing stock of material wealth around the world. Its extent and severity are demonstrated by the number of poor people across the planet, and inequality and poverty go hand in hand.

Ravallion (2005) observed a non-linear relationship between growth-poverty elasticity and the initial inequality level in a set of underdeveloped countries and argued that economic growth had little effect on the poor if inequality was not thereby reduced. It is estimated that growth of $1.0 \%$ can reduce poverty by up to $4.3 \%$ in countries with low inequality. In countries that suffer from high income inequality, however, the same $1.0 \%$ growth only yields a $0.6 \%$ decrease in the percentage of poor people.

Therefore, one of the factors affecting poverty reduction rates for a given growth rate is the change in income distribution. This was also found by Datt and Ravallion (2002) when they measured poverty changes resulting from the growth-income distribution effect. Models designed to estimate the elasticity of poverty reduction must incorporate income inequality as an explanatory variable to prevent changes in income distribution being subsumed into growth elasticity.

According to Bourguignon (2004), the reduction of income inequality is an important tool in reducing poverty, and economic growth may not be such a necessary element. Similar results were found in Brazil by Barros, Henriques and Mendonça (2001). These authors emphasized that inequality in income distribution was responsible for economic growth being less efficient than it might be for poverty reduction purposes. In other words, the effect of growth on poverty reduction was smaller in Brazil than in other countries with the same income level.

Only a few studies have sought to explain the connection between poverty, growth and inequality in Brazil. According to Rocha (2006), although poverty in Brazil has persisted for decades, it was only after the inflation problem was solved that social problems started to be treated as a priority, the reduction of inequality being an example. This may account for the small output of articles studying the poverty-growth-inequality triangle in Brazil.

Barreto (2005) considers that poverty reduction can be quickly achieved when a growing country achieves a less unequal income distribution. Therefore, the implementation of public policies aimed at the reduction of inequality, besides solving this problem, may also indirectly help towards other economic policy goals such as increased growth rates and poverty reduction. In general, the literature suggests that a significant reduction in poverty rates is a consequence of economic growth combined with policies to reduce income inequality. The joint result of these two effects is that poverty reduction feeds through directly into improvements in the average income of the poorest. 
Rocha (2006), for instance, indicates that the proportion of poor people in Brazil was reduced by nearly two percentage points between 2001 and 2004. According to this author, the reduction that occurred in the early years of the decade was a consequence of several factors that had differing regional impacts, including distributive changes in labour yield and the expansion of welfare benefits.

Rocha (2006) argues that poverty in Brazil is highly persistent mainly because of inequality and that it can be reduced through both income growth and better distribution, the consensus being, however, that the emphasis should be on reducing income inequality, since relying on income growth without progress on inequality may result in the goal of poverty elimination being deferred to a distant future.

Poverty reduction rates in Brazil from 1995 to 2009 are shown in table 1. The proportion of poor people $\left(P_{0}\right)$ fell from $38.70 \%$ in 1995 to $23.50 \%$ in 2009, a figure that, while still high, represents a reduction of 15.20 percentage points.

Table 1

Poverty rates in Brazil, 1995-2009

(Percentages)

\begin{tabular}{llll}
\hline Year & $P_{0}$ & Year & $P_{0}$ \\
\hline 1995 & 38.7 & 2003 & 39.1 \\
\hline 1996 & 38.1 & 2004 & 37.0 \\
\hline 1997 & 38.5 & 2005 & 34.1 \\
\hline 1998 & 37.2 & 2006 & 29.6 \\
\hline 1999 & 39.0 & 2007 & 28.0 \\
\hline 2001 & 38.3 & 2008 & 25.4 \\
\hline 2002 & 38.2 & 2009 & 23.5 \\
\hline Difference -15.20 & & & \\
\hline
\end{tabular}

Source: Prepared by the authors, on the basis of data from the National Household Survey (PNAD).

Thus, analysis of this indicator shows that there was significant poverty reduction in Brazil during the 1995-2009 period.

\section{Growth versus inequality}

The literature has analysed the economic growth versus inequality relationship, taking into consideration the causalities behind these two variables. Many of the issues relating to them have to do with the way inequality is generated and reproduced over time and the way inequality and economic development processes are connected.

The Kuznets (1955) inverted-U hypothesis is the starting point for this theory. According to this, inequality should first increase with the beginnings of economic development as the economy moves from the rural sectors towards industrialization (transfer of labour from the less productive to the more productive sector). Later on, once the bulk of the labour force is working in the industrial sector, inequality should diminish.

Thus, a development policy could be summarized as the promotion of economic growth in a way that also serves to reduce inequality. With higher and better-distributed incomes, the problem of poverty should be solved.

According to Barreto (2005), a number of studies have analysed the impact of inequality on economic growth. Different models show that inequality may either retard or stimulate growth. 
For example, Alesina and Rodrik (1994) established that the causality between growth and inequality was based on three things: (i) government spending and redistributive tax policies should be negatively related to growth because of their perverse effects on capital accumulation; (ii) tax aliquots should tend to be proportional to income, and the benefits of public expenditure should be available to all individuals alike, with the implication that spending levels should be inversely related to income; and (iii) the tax burden adopted by the government should be the one desired by the median voter, implying less capital accumulation and therefore less growth.

Stewart (2000) takes the approach that inequality should be negative for growth, arguing that: (i) high inequality means political instability, uncertainty, less investment and less growth; (ii) high inequality results in a populist redistributive taxation policy, disincentive effects and lower growth rates; and (iii) high inequality affects the behaviour of the richest, who press for preferential tax treatment, leading to overinvestment in certain areas and therefore to lower growth.

There are others, though, who consider that inequality may stimulate economic growth. Bourguignon (1981) argues that the tendency to save is different for the rich and the poor, being higher among the former than the latter, which would imply a tendency for investment to be greater in more unequal economies, with the corollary of potentially faster growth. Conversely, authors such as Barro (2000) and López (2004) do not find any relationship whatsoever between inequality and economic growth and maintain that investment levels do not significantly depend on inequality. Some income inequality data for Brazil between 1995 and 2009 are shown in table 2. These data are the Gini index, the ratio between the income of the richest $10 \%$ and the poorest $40 \%$, the ratio between the income of the richest $20 \%$ and the poorest $20 \%$, the ratio between the income of the richest $10 \%$ and the poorest $10 \%$, the average per capita household income and the percentage of people below the poverty line.

Table 2 shows that the income of the richest 10\% in Brazil was 23.7 times as great as that of the poorest $40 \%$ in 1995, falling to 16.3 times by 2009 . The ratios of the incomes of the richest $10 \%$ relative to the poorest $10 \%$ and of the richest $20 \%$ relative to the poorest $20 \%$ also declined significantly during the period, especially the former, which moved down from 67.0 to 43.8. Meanwhile, per capita family income grew by approximately $22.5 \%$. The last column shows that the proportion of people below the poverty line stabilized at around 19\%, then fell to $12 \%$ in 2009.

Table 2

Main per capita family income distribution statistics in Brazil, 1995-2009

\begin{tabular}{lcccccc}
\hline Year & Gini & $\begin{array}{c}\text { Income of richest } \\
10 \% \text { as multiple } \\
\text { of poorest 40\% }\end{array}$ & $\begin{array}{c}\text { Income of richest } \\
20 \% \text { as multiple } \\
\text { of poorest 20\% }\end{array}$ & $\begin{array}{c}\text { Income of richest } \\
10 \% \text { as multiple } \\
\text { of poorest 10\% }\end{array}$ & $\begin{array}{c}\text { Average family } \\
\text { income per capita } \\
\text { (reais per month) }\end{array}$ & $\begin{array}{c}\text { People below the } \\
\text { poverty line } \\
\text { (percentages) }\end{array}$ \\
\hline 1995 & 0.601 & 23.7 & 27.4 & 67.0 & 520.6 & 19.7 \\
\hline 1996 & 0.602 & 24.2 & 29.3 & 74.9 & 529.7 & 19.5 \\
\hline 1997 & 0.602 & 24.2 & 28.7 & 72.3 & 529.0 & 19.8 \\
\hline 1998 & 0.601 & 23.6 & 27.5 & 67.2 & 534.5 & 19.1 \\
\hline 1999 & 0.595 & 22.7 & 26.2 & 63.2 & 504.4 & 19.9 \\
\hline 2001 & 0.597 & 22.9 & 26.9 & 68.4 & 511.9 & 19.7 \\
\hline 2002 & 0.590 & 21.9 & 24.7 & 59.2 & 511.9 & 19.5 \\
\hline 2003 & 0.585 & 21.1 & 24.3 & 59.4 & 481.9 & 20.1 \\
\hline 2004 & 0.575 & 19.5 & 22.0 & 51.7 & 497.9 & 18.9 \\
\hline 2005 & 0.572 & 19.2 & 21.3 & 49.7 & 528.4 & 17.5 \\
\hline 2006 & 0.560 & 18.3 & 20.4 & 47.5 & 577.5 & 15.2 \\
\hline 2007 & 0.550 & 17.7 & 20.2 & 49.0 & 592.5 & 14.4 \\
\hline 2008 & 0.540 & 16.8 & 18.9 & 44.0 & 622.6 & 12.9 \\
\hline 2009 & 0.540 & 16.3 & 18.6 & 43.8 & 637.4 & 12.2 \\
\hline
\end{tabular}

Source: Institute for Studies on Labour and Society (IETS).

Note: The 2009 poverty line of 196.00 reais is taken, deflated by the national consumer price index (INPC). 
These data show that income inequality in Brazil has declined in recent years, corroborating results obtained by Neri (2006), Barros and others (2007) and Hoffmann (2007). Similarly, Manso, Barreto and Tebaldi (2005) found a significant reduction of income inequality in Brazil after the Real Plan was implemented. From 1995 to 2004, there was a 2.71\% reduction in the Gini index.

\section{The elasticity of poverty to inequality and income}

The purpose of establishing income-poverty and inequality-poverty elasticities is to analyse the poverty impact of growth and changes in income inequality. This methodology was originally proposed by Bourguignon (2003).

That author follows the classic definition proposed by Foster, Greer and Thorbecke (1984), whereby poverty is measured by the percentage of poor people. On that basis, the proportion of persons with a per capita income below the poverty line is given by:

$$
H_{t}=\operatorname{Pr}\left(y_{t}<z\right) \equiv F_{t}(z)
$$

where the function $F_{t}(z)$ is given by the income distribution function.

Therefore, the proportion of the population with an income below the absolute poverty line $z$ at time $t$ is equal to the probability that income $y_{t}$ is below the poverty line. The change in the percentage of poor people between two time periods $t$ and $t^{\prime}$ is accordingly:

$$
\Delta H=H_{t^{\prime}}-H_{t}=F_{t^{\prime}}(z)-F_{t}(z)
$$

Assuming that the income distribution curve is log-normal, Bourguignon (2003) defines the original curve displacement shown in figure 1, with the final distribution curve in respect of poverty variation being as follows:

$$
\Delta H=H_{t^{\prime}}-H_{t} \approx\left[F_{t}\left(\frac{z}{\bar{y}_{t^{\prime}}}\right)-F_{t}\left(\frac{z}{\bar{y}_{t}}\right)\right]+\left[F_{t^{\prime}}\left(\frac{z}{\bar{y}_{t^{\prime}}}\right)-F_{t}\left(\frac{z}{\bar{y}_{t^{\prime}}}\right)\right]
$$

The first expression in brackets corresponds to the growth effect, while the relative income distribution $F_{t}$ is kept constant. The second expression is for the inequality effect, and there is a shift in the distribution of relative income, which remains constant.

Thus considered, changes in poverty are influenced by two effects: the first is due to income growth and the second is a consequence of the inequality of income distribution.

According to Epaulard (2003), the relative change in poverty resulting from income growth and the redistribution effect may be decomposed as follows:

$$
\frac{d H}{d t}=\frac{\partial H_{t}}{\partial \bar{y}_{t}} \frac{d \bar{y}_{t}}{d t}+\frac{\partial H_{t}}{\partial G_{t}} \frac{d G_{t}}{d t}
$$

In terms of elasticity we have:

$$
\frac{d H}{d t}=\varepsilon_{y}^{H} \frac{d \bar{y}_{t}}{d t} \frac{H_{t}}{\bar{y}_{t}}+\varepsilon_{G}^{H} \frac{H_{t}}{G_{t}} \frac{d G_{t}}{d t}
$$


where the Gini coefficient is defined as $G=2 \Phi\left(\frac{\sigma_{t}}{\sqrt{2}}\right)-1$. The term $\Phi(\cdot)$ is the cumulative density function for the standard normal distribution (the normal distribution with a mean of zero and a standard deviation of 1) and $\sigma_{t}$ is the standard deviation of the income logarithm. Thus, Epaulard (2003) proves that the income-poverty elasticity $\varepsilon_{y}^{H}$ and the inequality-poverty elasticity $\varepsilon_{G}^{H}$ are defined by the following expressions:

$$
\begin{gathered}
\varepsilon_{\bar{y}}^{H}=\frac{\partial H_{t}}{\partial y_{t}} \frac{\bar{y}_{t}}{H_{t}} \equiv-\frac{1}{\sigma_{t}} \frac{\varnothing\left(\frac{\log \left(z / \bar{y}_{t}\right)}{\sigma_{t}}+\frac{1}{2} \sigma_{t}\right)}{\Phi\left(\frac{\log \left(z / \bar{y}_{t}\right)}{\sigma_{t}}+\frac{1}{2} \sigma_{t}\right)} \leq 0 \\
\varepsilon_{G}^{H}=\frac{\partial H_{t}}{\partial \sigma_{t}} \frac{\sigma_{t}}{H_{t}} \equiv \frac{1}{\sigma_{t}} \frac{\varnothing\left(\frac{\log \left(z / \bar{y}_{t}\right)}{\sigma_{t}}+\frac{1}{2} \sigma_{t}\right)}{\Phi\left(\frac{\log \left(z / \bar{y}_{t}\right)}{\sigma_{t}}+\frac{1}{2} \sigma_{t}\right)}\left(\frac{\log \left(z / \bar{y}_{t}\right)}{\sigma_{t}}+\frac{1}{2} \sigma_{t}\right) \gtreqless 0
\end{gathered}
$$

The author referred to also shows that the income-poverty elasticity $\left(\varepsilon_{\bar{y}}^{H}\right)$ and the inequalitypoverty elasticity $\left(\varepsilon_{G}^{H}\right)$ decrease in absolute terms at the poverty line and average income ratios $\left(z / \bar{y}_{t}\right)$ and with the standard deviation of the income logarithm $\left(\sigma_{t}\right)$. Income-poverty elasticity is always positive or null. On the other hand, inequality-poverty elasticity may be higher or lower than zero. ${ }^{1}$

Consequently, the effect of changes in income distribution on poverty reduction is the function of income growth and the level of inequality. This means that poverty changes may result both from economic growth (typified by the increase of average income) and from a decline in income inequality. However, the poverty reduction effect is much stronger when both factors combine.

\section{The database}

The data used in the estimation of the econometric models described in the next section were obtained from the National Household Survey (PNAD) published by the Brazilian Geographical and Statistical Institute (IBGE). The sample is composed of all Brazilian states for the years from 1995 to 2009.²

The family income per capita variable is calculated by dividing total family income by the number of family members. The arithmetic average of this variable is then established and average income values thus obtained for the states in the sample. We expect to find a negative relationship between poverty and this variable. It is worth noting that the Brazilian economy showed growth in income per capita over the period 1995-2009.

In this article, families living on a per capita family income insufficient to meet their basic needs are classified as poor. Thus, the absolute poverty indicator used is the proportion of poor people $\left(P_{0}\right)$.

\footnotetext{
1 According to Epaulard (2003), inequality-poverty elasticity should be positive unless a country has a very low average income. This elasticity will be positive as long as $\bar{y}_{t}<z \exp \left(-\frac{1}{2} \sigma_{t}^{2}\right)$.

2 The PNAD was not carried out in 2000. To fill this gap, we have taken arithmetic averages of variables from 1999 to 2001. The old states of the northern region were not included in the sample owing to the non-availability of data from rural areas before 2004.
} 
The poverty line adopted to construct this indicator was half the monthly minimum wage. ${ }^{3}$ The poverty indicator $P_{0}$ is defined as $P_{0}=\frac{q}{n}$, where $n$ is the total number of individuals and $q$ is the number of people with a per capita family income below the poverty line.

The inequality measurement method used is the Gini coefficient, calculated on the basis of per capita family income as extracted from the PNAD. This index is frequently used to express income inequality and may be linked to the so-called Lorenz curve, which is defined by the set of points obtained by plotting income shares against population shares in ascending order. On the basis of this curve, we then calculate Gini coefficients for each of the states between 1995 and 2009. As discussed in the previous section, the relationship between the Gini coefficient and poverty must be positive. In other words, the higher the inequality, the more poverty there is.

It is important to emphasize that all monetary variables have been adjusted to real 2009 values using the national consumer price index (INPC) prepared with 2009 data.

\section{The econometric model}

The econometric specification of the model is based on the contribution of economic growth and shifts in income distribution to changes in poverty. We admit as a hypothesis that the current poverty trend tends to perpetuate itself, affect future poverty performance or both. ${ }^{4}$ To explore this, the relationship between changes in poverty and their determinants is investigated using a dynamic panel data regression model defined as follows: ${ }^{5}$

$$
\Delta \ln \left[P_{0, i t}\right]=\beta_{0}+\beta_{1} \Delta \ln \left[P_{0, i t-1}\right]+\beta_{2} \Delta \ln \left[\bar{Y}_{i t}\right]+\beta_{3} \Delta \ln \left[\text { Gini }_{i t}\right]+\eta_{t}+\mu_{i t}
$$

The variables of this model are defined as: $\Delta \ln P_{0, i t}=\ln P_{0 ; i t}-\ln P_{0 ; i t-1}$, representing the change in the proportion of people who are poor between two periods of time; $\Delta \ln \bar{Y}_{i t}=\ln \bar{Y}_{i t}-\ln \bar{Y}_{i t-1}$, the change in the average family income per capita; and $\Delta \ln G_{i n i} i_{i t}=\ln G i n i_{i t}-\ln G i n i_{i t-1}$, the change in income concentration as measured by the Gini coefficient $i$; while $\eta_{i}$ represents the non-observable random effects of individuals and $\mu_{i t}$ represents random disturbances. The model variables are defined using a natural logarithm in which subscript $i$ represents the state and $t$ the time period. Thus, parameters $\beta_{2}$ and $\beta_{3}$ are income-poverty elasticity $\varepsilon_{y}^{P_{0}}$ and inequality-poverty elasticity $\varepsilon_{G}^{P_{0}}$. Note that these elasticities do not change over time.

An expansion of this model introduced by Kalwij and Verschoor (2004) allows the income and inequality elasticities to change over time depending on the inverse initial development level (poverty line divided by initial family income per capita and the initial inequality level). ${ }^{6}$ By entering these variables in the model, we intend to evaluate the hypothesis that growth is less effective at reducing poverty when initial inequality is higher (Bourguignon hypothesis). This dynamic model is described as follows:

3 This line was also used by Rocha (2006), Barreto (2005) and Marinho and Soares (2003). However, the shift line may alter the outcome.

4 Ribas, Machado and Golgher (2006) found evidence of poverty persistence in Brazil.

5 This model may be seen in Bourguignon (2003) and in Kalwij and Verschoor (2004). However, those authors do not think that poverty can develop dynamic behaviour.

6 Kalwij and Verschoor (2004) likewise do not give consideration to poverty behaving dynamically over time. 


$$
\begin{gathered}
\Delta \ln \left[P_{0, i t}\right]=\beta_{0}+\beta_{1} \Delta \ln \left[P_{0, i t-1}\right]+\beta_{2} \Delta \ln \left[\bar{y}_{i t}\right]+\beta_{3} \Delta \ln [\bar{y}] \ln \left[G_{i 0}\right]+\beta_{4} \Delta \ln \left[\bar{y}_{i t}\right] \ln \left[\frac{z_{i t}}{y_{i 0}}\right] \\
\beta_{5} \Delta \ln \left[\operatorname{Gini}_{i t}\right]+\beta_{6} \Delta \ln \left[\operatorname{Gini}_{i t}\right] \ln \left[\operatorname{Gini}_{i 0}\right]+\beta_{7} \Delta \ln \left[\operatorname{Gini}_{i t}\right] \ln \left[\frac{z_{i t}}{\bar{y}_{i 0}}\right]+\beta_{8} \ln \left[G_{i 0}\right] \\
\beta_{9} \ln \left[\frac{z_{i t}}{\bar{y}_{i 0}}\right]+\eta_{i}+\mu_{i t}
\end{gathered}
$$

where in addition to the variables $\Delta \ln \left[P_{i t}\right], \Delta \ln \left[\bar{y}_{i t}\right]$ and $\Delta \ln \left[\right.$ Gini $\left._{i t}\right]$, which follow the formulations previously described, we have $\Delta \ln \left[\bar{y}_{i t}\right] \ln \left[G_{i 0}\right]$ and $\Delta \ln \left[\bar{y}_{i t}\right] \ln \left[\frac{z_{i t}}{y_{i 0}}\right]$, representing the interactions between average family income per capita and the initial Gini index at state $i\left(G_{i 0}\right)$ and the inverse initial development level $\frac{z_{i t}}{y_{i 0}}$ (poverty line divided by initial family income per capita). Likewise, the variables $\Delta \ln \left[\operatorname{Gini}_{i t}\right] \ln \left[G_{i 0}\right]$ and $\Delta \ln \left[\operatorname{Gini}_{i t}\right] \ln \left[\frac{z_{i t}}{\bar{y}_{i 0}}\right]$ represent the interactions between the Gini inequality index and the initial inequality index associated with state i and the inverse initial development level.

The hypotheses adopted in these models are $E\left[\eta_{i}\right]=E\left[\mu_{i t}\right]=E\left[\eta_{i} \mu_{i t}\right]=0$ and $E\left[\mu_{i t} \mu_{i s}\right]=0$ for $i=1.2, \ldots ., N$ e $\forall t \neq s$. Additionally, there is a standard hypothesis relating to the initial conditions: $\Delta \ln P_{i t}$ : $E\left[\Delta \ln P_{i t-1} \mu_{i t}\right]=0$ for $i=1.2, \ldots, N$ and $t=1.2, \ldots . ., T$ (Ahn and Schmidt, 1995).

The second model specification therefore takes into account that the poverty elasticities of average family income per capita and inequality depend on the initial inequality and the ratio between the poverty line and the initial average family income per capita.

Naturally, coefficients $\beta_{2}$ and $\beta_{5}$ are not interpreted as income elasticity and inequality elasticity. To calculate these elasticities, it is necessary to consider the interaction terms. Thus, the income-poverty and inequality-poverty elasticities are now respectively defined as:

$$
\begin{aligned}
& \varepsilon_{\bar{y}_{i t}}^{P_{0}}=\beta_{2}+\beta_{3} \ln \left[G_{i 0}\right]+\beta_{4} \ln \left[\frac{z_{i t}}{\bar{y}_{i 0}}\right] \\
& \varepsilon_{G_{i t}}^{P_{0}}=\beta_{5}+\beta_{6} \ln \left[G_{i 0}\right]+\beta_{7} \ln \left[\frac{z_{i t}}{\bar{y}_{i 0}}\right]
\end{aligned}
$$

We can now observe that the income-poverty and inequality-poverty elasticities do change through time.

The traditional estimation techniques are inappropriate for the two models shown because of two main econometric problems. The first is the presence of unobservable effects of individuals $\eta_{i}$, together with the lagged dependent variable $\Delta \ln P_{k, i t-1}$, on the right-hand side of the equation. In this case, omitting the individual fixed effects in the dynamic panel model makes the ordinary least square (OLS) estimators biased and inconsistent.

For example, the provable positive correlation between the lagged dependent variable and the fixed effects means that the coefficient $\beta_{1}$ estimator is upward-biased. On the other hand, the withingroups estimator (which corrects for the presence of fixed effects) generates a downward-biased estimation of $\beta_{1}$ in panels with a small temporal dimension (Judson and Owen, 1999).

Seeking to correct these problems, Arellano and Bond (1991) proposed a GMM-differentiated estimator. This method consists in eliminating fixed effects through the first-difference equation. Therefore, for the two models we have: 


$$
\begin{gathered}
\Delta\left[\Delta \ln \left[P_{0, i t}\right]\right]=\beta_{1} \Delta\left[\Delta \ln \left[P_{0, i t-1}\right]\right]+\beta_{2} \Delta\left[\Delta \ln \left[\bar{Y}_{i t}\right]\right]+\beta_{3} \Delta \Delta\left[\ln \left[G i n i_{i t}\right]\right]+\Delta \mu_{i t} \\
\Delta\left[\Delta \ln \left[P_{0, i t}\right]\right]=\beta_{0}+\beta_{1} \Delta\left[\Delta \ln \left[P_{0, i t-1}\right]\right]+\beta_{2} \Delta\left[\Delta \ln \left[\bar{Y}_{i t}\right]\right]+\beta_{3} \Delta\left[\Delta \ln [\bar{Y}]\left[G_{i 0}\right]\right] \\
+\beta_{4} \Delta\left[\Delta \ln \left[\bar{y}_{i t}\right] \ln \left[\frac{z_{i t}}{\bar{y}_{i 0}}\right]\right]+\beta_{5} \Delta\left[\Delta \ln \left[G i n i_{i t}\right]\right]+\beta_{6} \Delta\left[\Delta \ln \left[G i n i_{i t}\right] \ln \left[G_{i 0}\right]\right] \\
+\beta_{7} \Delta\left[\Delta \ln \left[\operatorname{Gini}_{i t}\right] \ln \left[\frac{z_{i t}}{\bar{y}_{i 0}}\right]\right]+\beta_{8} \Delta\left[\Delta \ln \left[G_{i 0}\right]\right]+\beta_{9} \Delta\left[\ln \left[\frac{z_{i t}}{\bar{y}_{i 0}}\right]\right]+\Delta \mu_{i t}
\end{gathered}
$$

where for a variable $w_{i t}$, any $\Delta \ln \left[w_{i t}\right]=\ln \left[w_{i t}\right]-\ln \left[w_{i t-1}\right]$. Through the construction of equations (12) and (13), $\Delta\left[\Delta \ln \left[P_{0, i t-1}\right]\right]$ and $\Delta \mu_{i t}$ are correlated, and consequently OLS estimators for their coefficients will be biased and inconsistent. Accordingly, it is necessary to implement instrumental variables for $\Delta\left[\Delta \ln \left[P_{0, i t-1}\right]\right]$ in this case. The set of hypotheses adopted for equations (8) and (9) implies that the moment condition $E\left[\Delta\left[\Delta \ln P_{0, i t-S}\right] \Delta \mu_{i t}\right]=0$ for $t=3.4, \ldots . T$ and $s \geq 2$ are valid. On the basis of these moments, Arellano and Bond (1991) suggest using $\Delta \ln \left[P_{0, i t-s}\right]$ for $t=3.4, \ldots . T$ and $s \geq 2$ as instruments for equations (12) and (13).

With regard to the other explanatory variables, there are three possible situations. An explanatory variable $x_{i t}$ may be classified as (i) strictly exogenous if it is not correlated to the past, present and future error terms, (ii) frankly exogenous if it is only correlated to past error terms and (iii) endogenous if it is correlated to the past, present and future error terms. In the second case, $x_{i t}$ lagged values for one or more periods are valid instruments for the estimation of equations (12) and (13). In the last case, $x_{i t}$ lagged values for two or more periods are valid instruments for the estimations of these same equations.

On the other hand, Arellano and Bover (1995) and Blundell and Bond (1998) affirm that these instruments are weak when the dependent and explanatory variables show a strong persistence or the relative variance of fixed effects increases, or both. This produces a differentiated GMM estimator that is inconsistent and biased for small $T$ panels.

Therefore, the aforementioned authors suggest an estimation using a system that combines the set of level equations (8) and (9) and difference equations (12) and (13) as a way of reducing the bias and imprecision problems. This is where the generalized method of moments comes from (GMM system). For difference equations, the set of instruments is the same as described above. For a level regression, the appropriate instruments are the lagged differences of the respective variables. For instance, if it is assumed that the differences in the explanatory variables are not correlated to the individual fixed effects for $t=3.4, \ldots . T$ and $E\left[\Delta\left[\Delta \ln P_{0, i 2}\right] \eta_{i}\right]=0$ for $i=1.2 .3, \ldots, N$, then the different explanatory variables and $\left.\Delta\left[\Delta \ln P_{k, i t-1}\right] \eta_{i}\right]$, if they are either exogenous or frankly exogenous, are still valid instruments for level equations. The same happens if they are endogenous, but with instruments that are the explanatory variables in one-period lagged difference and $\Delta\left[\Delta \ln P_{k, i t-1}\right]$.

Finally, and as a means of testing model robustness and consistency, Arellano and Bond (1991) suggest two different test types: the Hansen and Sargan tests, which check whether the instruments used and the additional instruments required by the GMM system are valid. Lastly, the Arellano and Bond statistical tests verify whether the error $\mu_{i t}$ has a first-order serial correlation and whether $\Delta \mu_{i t}$ shows second-order correlation. For the purposes of estimator consistency, $\mu_{i t}$ is expected to result in a first-order correlation while the $\Delta \mu_{i t}$ series should not be second-order-correlated.

It is worth stressing that the GMM system introduced in the next section derives from the estimation performed with the estimator as corrected by the Windmeijer (2005) method, with a view to preventing 
the variance estimator from underestimating the true variances in a finite sample. The estimator applied was suggested by Arellano and Bond (1991) in two steps. In the first step, the error terms are assumed to be independent and homoscedastic through time in their respective states. In the second stage, residuals obtained in the first stage are used to build a consistent estimation of a variance-covariance matrix, thus relaxing the independence and homoscedasticity hypothesis. The second-stage estimator is asymptotically more efficient than the first-stage estimator.

\section{Econometric model results}

This section introduces the results of estimations for the parameters of the two models, which will be used to calculate the income-poverty and inequality-poverty elasticities.

The results estimated for the first model using the OLS, within-groups and GMM system methods can be seen in table 3 .

Table 3

Results of regression models for $\Delta \ln \left[P_{0, i t}\right]$ : model 1

\begin{tabular}{|c|c|c|c|c|c|c|}
\hline & \multicolumn{2}{|c|}{$\begin{array}{l}\text { Ordinary least squares } \\
\qquad[\mathrm{a}]\end{array}$} & \multicolumn{2}{|c|}{$\begin{array}{l}\text { Within-group } \\
{[\mathrm{b}]}\end{array}$} & \multicolumn{2}{|c|}{$\begin{array}{l}\text { Generalized method of } \\
\text { moments system } \\
{[\mathrm{c}]}\end{array}$} \\
\hline & Coefficient & P-value & Coefficient & P-value & Coefficient & P-value \\
\hline$\Delta \ln \left[P_{0, i t-1}\right]$ & $\begin{array}{c}0.1840 \\
(0.0672)\end{array}$ & 0.00 & $\begin{array}{c}0.1529 \\
(0.0686)\end{array}$ & 0.02 & $\begin{array}{c}0.1139 \\
(0.0239)\end{array}$ & 0.00 \\
\hline$\Delta \ln \left[\bar{y}_{i t}\right]$ & $\begin{array}{l}-0.7654 \\
(0.0651)\end{array}$ & 0.00 & $\begin{array}{c}-0.7886 \\
(0.0658)\end{array}$ & 0.00 & $\begin{array}{c}-0.6899 \\
(0.0507)\end{array}$ & 0.00 \\
\hline$\Delta \ln \left[\right.$ Gini $\left._{i t}\right]$ & $\begin{array}{c}0.8785 \\
(0.1451)\end{array}$ & 0.00 & $\begin{array}{c}0.9046 \\
(0.1464)\end{array}$ & 0.00 & $\begin{array}{c}0.7799 \\
(0.1385)\end{array}$ & 0.02 \\
\hline \multirow[t]{2}{*}{ Constant } & $\begin{array}{c}-0.0079 \\
(0.0049)\end{array}$ & 0.11 & $\begin{array}{l}-0.0080 \\
(0.0050)\end{array}$ & 0.10 & $\begin{array}{c}-0.0114 \\
(0.0007)\end{array}$ & 0.00 \\
\hline & \multicolumn{2}{|c|}{$\begin{array}{l}F(3.269)=53.11 \\
\text { Prob }>F=0.0000 \\
R^{2}=0.37\end{array}$} & \multicolumn{2}{|c|}{$\begin{array}{l}F(3.249)=53.21 \\
\text { Prob }>F=0.0000\end{array}$} & \multicolumn{2}{|c|}{$\begin{array}{l}F(2.20)=124.30 \\
\text { Prob }>F=0.0000\end{array}$} \\
\hline \multicolumn{3}{|c|}{$\mathrm{H}_{0}$ : Absence of autocorrelation in first-order residuals } & \multicolumn{2}{|c|}{ P-value } & \multicolumn{2}{|c|}{0.001} \\
\hline \multicolumn{3}{|c|}{$\mathrm{H}_{0}$ : Absence of autocorrelation in second-order residuals } & \multicolumn{2}{|c|}{ P-value } & \multicolumn{2}{|c|}{0.101} \\
\hline \multicolumn{3}{|c|}{ Hansen test } & \multicolumn{2}{|c|}{ Prob $>$ chi $^{2}$} & \multicolumn{2}{|c|}{0.288} \\
\hline \multicolumn{3}{|l|}{ Sargan test } & \multicolumn{2}{|c|}{ Prob $>$ chi $^{2}$} & \multicolumn{2}{|c|}{0.262} \\
\hline
\end{tabular}

Source: Prepared by the authors.

Note: (i) the values in parentheses are the standard deviations corrected by the Windmeijer method (2005); (ii) the Hansen test values are the p-values for the null hypothesis that the instruments are valid; (iii) the Sargan test values are the $\mathrm{p}$-values for the validity of the additional instruments required by the GMM system, taking the explanatory variables in lagged differences as instruments for the GMM system and lagging $\Delta \ln \left[P_{0, i t-1}\right]$ and $\Delta \ln \left[\bar{y}_{i t}\right]$ by one period; (iv) there were 273 observations, 21 groups and 17 instruments.

In this table, the value of the coefficient estimated for the variable $\Delta \ln \left[P_{i t-1}\right]$ in column [c] by applying the GMM system method is within the values of the coefficients estimated for this same variable (columns [a] and [b] using the OLS and within-group methods). The GMM system thus reduces the problem of estimation bias, as there is a one-period lagged dependent variable on the right-hand side of equation (8). Note that in column [c] the statistical significance of the estimated coefficient of $\Delta \ln \left[P_{0, i t-1}\right]$ confirms the initial hypothesis that poverty variation is persistent.

The results estimated for the income elasticity and inequality elasticity parameters were -0.69 and 0.78 , respectively, as shown in column [c]. Thus, a 1.0\% increase in per capita income results in a decrease of $0.68 \%$ in the percentage of poor individuals. An increase of $1.0 \%$ in the inequality index leads to growth of $0.78 \%$ in poverty levels. It is worth remarking that the estimated elasticity values agree with the theoretical elasticity introduced in section III. They also corroborate results obtained in 
international papers such as those of Kalwij and Verschoor (2004), Bourguignon (2004) and Marinho and Soares (2003) and Hoffmann (2004) in Brazil. This indicates that policies aimed at reducing inequality are more effective at fighting poverty than those solely aimed at improving average income.

Estimated results for the parameters of equation (9) can be seen in table 4 below. Again, the value of the estimated parameter for the variable $\Delta \ln \left[P_{i t-1}\right]$ is within the range of the values estimated for this same variable (columns [a] and [b]) using the OLS and within-group methods. When estimated by the GMM system, this parameter is not statistically significant.

Table 4

Results of regression models for $\Delta \ln \left[P_{0, i t}\right]$ : model 2

\begin{tabular}{|c|c|c|c|c|c|c|}
\hline & \multicolumn{2}{|c|}{$\begin{array}{l}\text { Ordinary least squares } \\
\qquad[\mathrm{a}]\end{array}$} & \multicolumn{2}{|c|}{$\begin{array}{l}\text { Within-group } \\
{[\mathrm{b}]}\end{array}$} & \multicolumn{2}{|c|}{$\begin{array}{l}\text { Generalized method of } \\
\text { moments system } \\
\text { [c] }\end{array}$} \\
\hline & Coefficient & P-value & Coefficient & P-value & Coefficient & P-value \\
\hline$\Delta \ln P_{0, i t-1}$ & $\begin{array}{c}0.1463 \\
(0.0676) \\
\end{array}$ & 0.03 & $\begin{array}{c}0.0425 \\
(0.0720) \\
\end{array}$ & 0.55 & $\begin{array}{c}0.1301 \\
(0.0711)\end{array}$ & 0.08 \\
\hline$\Delta \ln \left[\bar{Y}_{i t}\right]$ & $\begin{array}{l}-0.3675 \\
(0.1485)\end{array}$ & 0.01 & $\begin{array}{l}-0.4137 \\
(0.1516)\end{array}$ & 0.00 & $\begin{array}{l}-1.0806 \\
(0.2936)\end{array}$ & 0.00 \\
\hline$\Delta \ln \left[\bar{Y}_{i t}\right] \ln \left[G_{i 0}\right]$ & $\begin{array}{c}0.4371 \\
(0.2629) \\
\end{array}$ & 0.09 & $\begin{array}{c}0.5238 \\
(0.2687)\end{array}$ & 0.05 & $\begin{array}{c}1.6851 \\
(0.5050)\end{array}$ & 0.00 \\
\hline$\Delta \ln \left[\bar{Y}_{i t}\right] \ln \left[\frac{z_{i t}}{\bar{y}_{i 0}}\right]$ & $\begin{array}{l}1.064 \\
(0.4832)\end{array}$ & 0.02 & $\begin{array}{l}1.0820 \\
(0.4801)\end{array}$ & 0.05 & $\begin{array}{c}1.1565 \\
(0.3860)\end{array}$ & 0.00 \\
\hline$\Delta \ln \left[\right.$ Gini $\left._{i t}\right]$ & $\begin{array}{c}0.4209 \\
(0.3479)\end{array}$ & 0.22 & $\begin{array}{l}0.4865 \\
(0.3507)\end{array}$ & 0.16 & $\begin{array}{l}3.4064 \\
(0.8328)\end{array}$ & 0.00 \\
\hline$\Delta \ln \left[\operatorname{Gini}_{i t}\right] \ln \left[G_{i 0}\right]$ & $\begin{array}{l}-0.3783 \\
(2.6100) \\
\end{array}$ & 0.53 & $\begin{array}{l}-0.5010 \\
(0.6166)\end{array}$ & 0.41 & $\begin{array}{l}-5.6068 \\
(1.4515)\end{array}$ & 0.00 \\
\hline$\Delta \ln \left[\operatorname{Gini}_{i t}\right] \ln \left[\frac{z_{i t}}{\bar{y}_{i 0}}\right]$ & $\begin{array}{l}-2.998 \\
(0.8709)\end{array}$ & 0.00 & $\begin{array}{l}-3.0703 \\
(0.8771)\end{array}$ & 0.00 & $\begin{array}{l}-1.2865 \\
(0.6120)\end{array}$ & 0.05 \\
\hline $\ln \left[G_{i 0}\right]$ & $\begin{array}{l}0.1283 \\
(0.1121) \\
\end{array}$ & 0.25 & & - & $\begin{array}{l}1.1980 \\
(0.5580)\end{array}$ & 0.04 \\
\hline $\ln \left[\frac{z_{i t}}{\bar{y}_{i 0}}\right]$ & $\begin{array}{l}-0.0931 \\
(0.0377)\end{array}$ & 0.01 & $\begin{array}{l}-0.2159 \\
(0.0479)\end{array}$ & 0.00 & $\begin{array}{l}0.2876 \\
(0.6176)\end{array}$ & 0.00 \\
\hline \multirow[t]{2}{*}{ Constant } & $\begin{array}{c}0.0851 \\
(0.0650)\end{array}$ & 0.19 & $\begin{array}{c}0.0491 \\
(0.1344)\end{array}$ & 0.00 & $\begin{array}{c}0.7001 \\
(0.3002)\end{array}$ & 0.03 \\
\hline & \multicolumn{2}{|c|}{$\begin{array}{l}F(9.63)=21.93 \\
\text { Prob }>F=0.0000 \\
R^{2}=0.43\end{array}$} & \multicolumn{2}{|c|}{$\begin{array}{l}F(8.244)=26.63 \\
\text { Prob }>F=0.0000\end{array}$} & \multicolumn{2}{|c|}{$\begin{array}{l}F(8.20)=16.24 \\
\text { Prob }>F=0.0000\end{array}$} \\
\hline \multicolumn{3}{|c|}{$\mathrm{H}_{0}$ : Absence of autocorrelation in first-order residuals } & \multicolumn{2}{|l|}{ P-value } & \multicolumn{2}{|c|}{0.002} \\
\hline \multicolumn{3}{|c|}{$\mathrm{H}_{0}$ : Absence of autocorrelation in second-order residuals } & \multicolumn{2}{|l|}{ P-value } & \multicolumn{2}{|c|}{0.829} \\
\hline \multicolumn{3}{|l|}{ Hansen test } & \multicolumn{2}{|c|}{ Prob $>$ chi $^{2}$} & \multicolumn{2}{|c|}{0.360} \\
\hline \multicolumn{3}{|l|}{ Sargan test } & \multicolumn{2}{|c|}{ Prob $>$ chi $^{2}$} & \multicolumn{2}{|c|}{0.269} \\
\hline
\end{tabular}

Source: Prepared by the authors.

Note: (i) the values in parentheses are the standard deviations corrected by the Windmeijer method (2005); (ii) the Hansen test values are the p-values for the null hypothesis that the instruments are valid; (iii) the Sargan test values are the $\mathrm{p}$-values for the validity of the additional instruments required by the GMM system, the instruments used in this system being the explanatory variables in lagged differences and $\Delta\left[\Delta \ln \left[P_{0, i t-1}\right]\right]$ and $\Delta\left[\Delta \ln \left[\bar{y}_{i t}\right]\right]$ lagged one period; (iv) there were 273 observations, 21 groups and 17 instruments.

Among the isolated factors that significantly contribute to poverty growth, mention may be made of the following, in order of increasing importance: the interaction between income changes and the inverse initial development level, the interaction between income changes and initial income inequality, and income inequality in the present. Column [c] in table 4 shows positive and significant values for these variables.

The interaction term between income changes and the inverse initial development level yields a positive and statistically significant estimated coefficient, and the same is true of the coefficient of interaction between income changes and the initial inequality level, as demonstrated by the values in column [c]. 
As the isolated average income effect on poverty is negative, the effect of an income increase on poverty reduction is smaller than when the initial development level is low. The same happens when the initial inequality index is high. These results confirm conclusions reached by Medina and Galván (2014b), who computed poverty elasticities and identified how poverty indicators, changes in income and the Lorenz curve were modified. They used household survey databases from 18 Latin American countries from 1997 to 2000 and the five years from 2002 to 2007 . The aim of the study is to measure the ability of income and inequality to influence poverty reduction on the basis of simulated counterfactual scenarios that take account of the sensitivity of poverty indices to changes in income and inequality levels. The analysis is carried out using all income distribution information available in each country. Decomposition methods designed to separate out changes in poverty into income growth and inequality effects are applied to simulate counterfactual scenarios that provide insight into the importance of changes in income inequality on the basis of the marginal proportional rate of substitution (MPRS) proposed by Kakwani. The results suggest that it would be wrong to propose the same policy options to all countries, as the sensitivity of the poverty rate depends on its initial level and the degree of inequality.

Accordingly, we can affirm that in regions with low initial development levels or high initial inequality, or both, the conditions for reducing poverty through income growth are relatively unfavourable. This being so, we can conclude that the high inequality and low initial development level of most Brazilian states are impediments to alleviating poverty by improving incomes.

As for the estimated coefficient in column [c] relating to the interaction between the change in inequality and the inverse initial development level, it is negative and statistically significant. The same is true of the interaction between the inequality variable and its initial level. Thus, the effect of the change in inequality on poverty reduction is smaller when the initial development level is low or when the initial inequality level is high. In other words, a decline in income inequality may be less effective at decreasing poverty in regions that suffer from a low initial development level, high initial inequality or both.

The low initial development level and high initial income inequality in Brazil therefore pose difficulties for poverty reduction, regardless of whether this is pursued by efforts to boost economic growth or to reduce income inequality.

This is borne out by the findings of Medina and Galván (2014a), who employed different econometric methodologies to analyse the contribution of economic growth and inequality to the evolution of poverty using a database of household surveys conducted in a set of 18 Latin American countries. The progress made on inequality, together with an increase in per capita income, explains the drop in poverty seen during the period 2002-2007. The results suggest that it is possible to reduce poverty by means of policies primarily designed to diminish the inequality of income distribution, especially in more developed countries, while in poorer economies there is also a need to increase the incomes of disadvantaged families as a necessary condition for reducing poverty. These authors found that an appropriate mix of policies to increase incomes and improve income distribution would generate a virtuous circle of rapid and sustained poverty reduction. Clearly, the sensitivity of poverty indicators to changes in average family income is correlated with the level of inequality, so that reducing income inequality improves the decline in poverty.

The inverse initial development coefficient has a positive and statistically significant relationship with the percentage of poor people (values in column [c]). Thus, the higher the inverse initial development level, the greater the incidence of poverty. Or to put it another way, the lower the initial level of family income per capita, the higher the incidence of poverty.

The last rows of table 4 introduce the Arellano and Bond (1991) test results for the first- and second-order residual autocorrelations and the Hansen and Sargan tests for instrument validity. Going by the $p$-values in column [c], the results of the Arellano and Bond tests suggest that we can reject the null hypothesis of absence of first-order autocorrelation and accept the existence of second-order 
residual autocorrelation. The p-values for the Hansen and Sargan tests allow us to accept the hypothesis that the instruments used in the model estimations are valid.

\section{Income-poverty and inequality-poverty elasticities in Brazilian states}

The income-poverty and inequality-poverty elasticities for Brazilian states were calculated in accordance with expressions (10) and (11). The parameters for these two expressions were obtained by estimating the second model, on the basis that this was more appropriate for determining these elasticities because it took account of income distribution characteristics, the inequality level and the initial development level. Table 5 gives average elasticities for the Brazilian states and regions from 1995 to 2009, and shows the standard deviations estimated.

Table 5

Average income-poverty and inequality-poverty elasticities in Brazilian states

\begin{tabular}{|c|c|c|c|c|}
\hline State & Income-poverty elasticity & Standard deviation & Inequality-poverty elasticity & Standard deviation \\
\hline Maranhão & -1.61 & & 2.33 & \\
\hline Piauí & -1.52 & & 2.30 & \\
\hline Ceará & -1.50 & & 2.34 & \\
\hline Rio Grande do Norte & -1.54 & & 2.30 & \\
\hline Paraíba & -1.53 & & 2.40 & \\
\hline Pernambuco & -1.56 & & 2.52 & \\
\hline Alagoas & -1.55 & & 2.50 & \\
\hline Sergipe & -1.56 & & 2.47 & \\
\hline Bahia & -1.57 & & 2.40 & \\
\hline North-east & -1.54 & 0.03 & 2.39 & 0.08 \\
\hline Minas Gerais & -1.58 & & 2.48 & \\
\hline Espírito Santo & -1.61 & & 2.51 & \\
\hline Rio de Janeiro & -1.63 & & 2.49 & \\
\hline São Paulo & -1.61 & & 2.42 & \\
\hline South-east & -1.60 & 0.02 & 2.47 & 0.03 \\
\hline Paraná & -1.59 & & 2.49 & \\
\hline Santa Catarina & -1.65 & & 2.38 & \\
\hline Rio Grande do Sul & -1.64 & & 2.47 & \\
\hline South & -1.62 & 0.03 & 2.44 & 0.05 \\
\hline Mato Grosso do Sul & -1.58 & & 2.49 & \\
\hline Mato Grosso & -1.61 & & 2.49 & \\
\hline Goiás & -1.59 & & 2.51 & \\
\hline Federal District & -1.62 & & 2.50 & \\
\hline Mid-west & -1.60 & 0.01 & 2.49 & 0.009 \\
\hline
\end{tabular}

Source: Prepared by the authors.

As expected from the signs of the theoretical income-poverty elasticity and inequality-poverty elasticity introduced in section III, the former is negative and the second positive for all Brazilian states and regions. In other words, growth in average income and the reduction of income inequality led to a fall in the number of poor individuals.

However, the values of these elasticities as shown in table 5 reveal that changes in income inequality have had a greater effect on poverty than average income growth. This matches the findings of Kakwani (1990) and Marinho and Soares (2003).

At the regional level, absolute values for income-poverty elasticity prove to be lower in the northeast than in the other regions. This result confirms the theoretical hypothesis that income-poverty 
elasticity is lower in economies with lower average incomes. In richer regions, average income growth has more influence on poverty reduction. These results confirm conclusions reached by Marinho and Soares (2003) and Hoffmann (2004). Consequently, less developed regions such as the Brazilian northeast have more difficulty reducing poverty through income growth. Likewise, inequality-poverty elasticity is also lower in the north-east than in the other regions, but changes in inequality have a greater impact on poverty than average income growth.

In general terms, these results suggest that inequality reduction policies are the most effective way of fighting poverty in Brazil.

\section{VII.Final considerations}

The aim of this article is to estimate poverty elasticities relative to income and inequality in Brazil in an effort to analyse the determinants of poverty reduction. More specifically, it assesses whether changes in poverty are the consequence of income redistribution, economic growth or both, bringing out the influence of each effect on poverty changes.

Estimation results for the first model showed that the income-poverty and inequality-poverty elasticities were -0.68 and 0.77 , respectively. This means that a $1.0 \%$ increase in per capita income results in a reduction of $0.68 \%$ in the proportion of poor people. Likewise, $1.0 \%$ growth in inequality leads to growth of $0.77 \%$ in poverty. It is important to note that these results corroborate findings in international studies such as those by Kalwij and Verschoor (2004) and Bourguignon (2004) as well as those by Marinho and Soares (2003) and Hoffmann (2004) for Brazil. The implication of these findings is that policies aimed at reducing inequalities are more effective at fighting poverty than those solely concerned with boosting average income.

Estimated results for the second model, which allows elasticities to change through time, showed that the factors contributing to poverty growth were, in order of increasing importance: the interaction between income changes and the inverse initial development level, initial income inequality, the interaction between income changes and initial income inequality, and income inequality in the present.

The impact of income growth on poverty reduction is smaller when the initial development level is low, and also when initial inequality is high. Thus, we can conclude that regions with a low initial development level or high initial inequality, or both, are less favourably positioned to reduce poverty through income growth. It is accordingly clear that the high inequality and low initial development of most Brazilian states are obstacles to reducing poverty by raising incomes.

The effect of changes in inequality on poverty reduction is likewise smaller when the initial development level is low or when initial inequality is high. Thus, attempting to fight poverty by reducing income inequality in Brazilian states or regions that suffer from low initial development levels, high initial inequality or both may not have the expected outcome.

As already pointed out, the low initial development level and high initial inequality of Brazil are barriers to reducing poverty regardless of whether this is addressed by boosting economic growth or reducing income inequalities.

With regard to the income-poverty and inequality-poverty elasticities, it transpired that the impact of income inequality on poverty was greater than that of average income growth. This was also observed by Kakwani (1990) and Marinho and Soares (2003).

At the regional level, the absolute value of poverty-income elasticity is lower in the north-east than in the other Brazilian regions. This result confirms the theoretical hypothesis that poverty-income elasticity is lower in economies with low average incomes. In richer regions, the effect of average income 
growth on poverty reduction is stronger. The results obtained in this article agree with the findings of Marinho and Soares (2003) and Hoffmann (2004). In short, less developed regions like the Brazilian north-east have more difficulty reducing poverty through income growth.

Likewise, inequality-poverty elasticity is lower in the north-east than in other regions, but the impact of inequality on poverty is higher than the impact of average income growth. Overall, these results suggest that inequality reduction policies are most effective when it comes to fighting poverty in Brazil.

\section{Bibliography}

Ahn, S. C. and P. Schmidt (1995), "Efficient estimation of models for dynamic panel data", Journal of Econometrics, vol. 68, No. 1, Amsterdam, Elsevier.

Alesina, A. and D. Rodrik (1994), "Distributive policies and economic growth", Quarterly Journal of Economics, vol. 109, No. 2, Oxford University Press.

Arellano, M. and O. Bover (1995), "Another look at the instrumental variable estimation of error-components model", Journal of Econometrics, vol. 68, No. 1, Amsterdam, Elsevier.

Arellano, M. and S. Bond (1991), "Some tests of specification for panel data: Monte Carlo evidence and an application to employment equations", The Review of Economic Studies, vol. 58, No. 2, Oxford University Press.

Barreto, F. A. F. D. (2005), “Crescimento econômico, pobreza e desigualdade: o que sabemos sobre eles?”, Série Ensaios sobre Pobreza, No. 1, Fortaleza, Federal University of Ceará.

Barro, R. (2000), "Inequality and growth in a panel of countries", Journal of Economic Growth, vol. 5, No. 1.

Barros, R. P. de and others (2007), "Determinantes da queda da desigualdade de renda Brasileira", Texto para Discussão, No. 1253, Rio de Janeiro, Institute of Economic Applied Research.

Barros, R. P. de, R. Henriques and R. Mendonça (2001), "A estabilidade inaceitável: desigualdade e pobreza no Brasil", Texto para Discussão, No. 800, Rio de Janeiro, Institute of Economic Applied Research.

Blundell, R. and S. Bond (1998), "Initial conditions and moment restrictions in dynamic panel data models", Journal of Econometrics, vol. 87, No. 1, Amsterdam, Elsevier.

Bourguignon, F. (2004), "The Poverty-Growth-Inequality Triangle”, Washington, D.C., World Bank [online] http:// siteresources.worldbank.org/INTPGI/Resources/342674-1206111890151/15185_ICRIER_paper-final.pdf. (2003), "The growth elasticity of poverty reduction: explaining heterogeneity across countries and time periods", Inequality and Growth: Theory and Policy Implications, T. Eicher and S. Turnovsky (eds.), Cambridge, Massachusetts, The MIT Press.

(1981), "Pareto superiority of unegalitarian equilibria in Stiglitz' model of wealth distribution with convex saving function", Econometrica, vol. 49, No. 6, New York, Econometric Society.

Chen, S. and Y. Wang (2001), "China's growth and poverty reduction: recent trends between 1990 and 1999", Policy Research Working Paper, No. 2651, Washington, D.C., World Bank.

Cline, W. R. (2004), Trade Policy and Global Poverty, Washington, D.C., Center for Global Development/ Institute for International Economics.

Datt, G. and M. Ravallion (2002), "Is India's economic growth leaving the poor behind?", Journal of Economic Perspectives, vol. 16, No. 3, Nashville, Tennessee, American Economic Association.

Deininger, K. and L. Squire (1996), "A new data set measuring income inequality", World Bank Economic Review, vol. 10, No. 3, Washington, D.C., World Bank.

Epaulard, A. (2003), "Macroeconomic performance and poverty reduction", IMF Working Paper, No. 03/72, Washington, D.C., International Monetary Fund (IMF).

Foster, J., J. Greer and E. Thorbecke (1984), "A class of decomposable poverty measures", Econometrica, vol. 52, No. 3, New York, Econometric Society.

Hoffmann, R. (2007), "Transferência de renda e a redução da desigualdade no Brasil e em cinco regiões entre 1997 e 2005”, Desigualdade de renda no Brasil: uma análise da queda recente, vol. 2, R. Paes de Barros, M. N. Foguel and G. Ulyssea (orgs.), Brasilia, Institute of Applied Economic Research. (2005), "Elasticidade da pobreza em relação à renda média e à desigualdade no Brasil e nas unidades da federação", Economia, vol. 6, No. 2, National Association of Centers for Post-graduation in Economics (ANPEC). 
(2004), "Elasticidade da pobreza em relação à renda média e à desigualdade" [online] http://www.anpec. org.br/encontro2004/artigos/A04A054.pdf.

(1995), "Desigualdade e pobreza no Brasil no período 1970-1990", Revista Brasileira de Economia, vol. 49, No. 2.

Kakwani, N. (1990), "Poverty and economic growth: with application to Côte d'Ivoire", Living Standards Measurement Study Working Paper, No. 63, Washington, D.C., World Bank.

Kalwij, A. and A. Verschoor (2004), "How good is growth for the poor? The role of the initial income distribution in regional diversity in poverty trends", CentER Discussion Paper Series, No. 115, CentER-Tilburg University.

Kraay, A. (2004), "When is growth pro-poor? Evidence from a panel of countries", Washington, D.C., Policy Research Working Paper, No. 3225, Washington, D.C., World Bank.

Kuznets, S. (1955), "Economic growth and income inequality", American Economic Review, vol. 45, No. 1, Nashville, Tennessee, American Economic Association.

Judson, R. A. and A. L. Owen (1999), "Estimating dynamic panel data models: a guide for macroeconomists", Economics Letters, vol. 65, No. 1, Amsterdam, Elsevier.

Lopez, J. H. (2004), "Pro-growth, pro-poor: is there a trade-off?", Policy Research Working Paper Series, No. 3378, Washington, D.C., World Bank.

Manso, C. A., F. A. Barreto and E. Tebaldi (2005), "O desequilíbrio regional brasileiro: novas perspectivas a partir das fontes de crescimento pró-pobre", Série Ensaios sobre Pobreza, No. 6, Fortaleza, Federal University of Ceará.

Marinho, E. and F. Soares (2003), "Impacto do crescimento econômico e da concentração de renda sobre a redução da pobreza nos estados brasileiros" [online] http://www.anpec.org.br/encontro2003/artigos/ B36.pdf.

Medina, F. and M. Galván (2014a), "Crecimiento económico, pobreza y distribución del ingreso. Fundamentos teóricos y evidencia empírica para América Latina, 1997-2007”, Estudios Estadísticos series, No. 82 (LC/L.3689), Santiago, Economic Commission for Latin America and the Caribbean (ECLAC). (2014b), "Sensibilidad de los índices de pobreza a los cambios en el ingreso y la desigualdad. Lecciones para el diseño de políicas en América Latina, 1997-2008", Estudios Estadísticos series, No. 87 (LC/L.3823), Santiago, Economic Commission for Latin America and the Caribbean (ECLAC).

Neri, M. (2006), "Desigualdade, estabilidade e bem-estar social”, Ensaios Econômicos, No. 637, Rio de Janeiro, Getulio Vargas Foundation.

Ravallion, M. (2005), "Pro-poor growth: a primer", Policy Research Working Paper, No. 3242, Washington, D.C., World Bank.

_ (2001), "Growth, inequality and poverty: looking beyond averages", World Development, vol. 29, No. 11, Amsterdam, Elsevier.

Ravallion, M. and S. Chen (1997), "What can new survey data tell us about recent changes in distribution and poverty?", World Bank Economic Review, vol. 11, No. 2, Washington, D.C., World Bank.

Ribas, R. P., A. F. Machado and A. B. Golgher (2006), "Fluctuations and persistence in poverty: a transientchronic decomposition model for pseudo-panel data", Texto para Discussão, No. 290, Federal University of Minas Gerais.

Rocha, S. (2006), Pobreza no Brasil. Afinal, de que se trata?, Rio de Janeiro, FGV Editora.

Salvato, M. A. and A. F. de Araujo Junior (2007), "Crescimento pró-pobre no Brasil: uma avaliação empírica da década de 1990", Texto para Discussão, No. 02, Minas Gerais, Pontifical Catholic University of Minas Gerais.

Stewart, F. (2000), Distribuição de renda e desenvolvimento, Brasilia, NEAD.

Son, H. H. (2004), "A note on pro-poor growth", Economics Letters, vol. 82, No. 3, Amsterdam, Elsevier.

Windmeijer, F. (2005), "A finite sample correction for the variance of linear efficient two-step GMM estimators", Journal of Econometrics, vol. 126, No. 1, Amsterdam, Elsevier. 